\author{
Shiva Hakimian \\ https://orcid.org/0000-0001-9328-4855 \\ Islamic Azad University Tehran South Branch \\ Faculty of Art and Architecture \\ hakimian.shiva@gmail.com

\section{Ali Afshar} \\ https://orcid.org/0000-0002-7483-2534 \\ Eqbal Lahoori Institute of Higher Education \\ Faculty of Architecture and Urban Planning \\ alafshar@gmail.com \\ Joanna Kowalczyk-Anioł \\ https://orcid.org/0000-0002-1547-9304 \\ University of Lodz \\ Faculty of Geographical Sciences \\ Institute of Urban Geography and Tourism Studies \\ CiTUR Centre for Tourism Research, Development and Innovation \\ Portugal \\ joanna.kowalczyk@geo.uni.lodz.pl
}

\title{
RETURNING LIFE TO THE CENTER OF TEHRAN: THE OUDLAJAN FOODSCAPE
}

\begin{abstract}
The Oudlajan revitalization project proposed in the article, relates to both its contemporary needs and its potential. In its idea, the project uses the Iranian tradition of 'hangout' and refers to current trends in spending leisure time as well as shaping (designing) inclusive urban space. In terms of purpose, the project presented is applied, and in terms of methods used, it is a descriptive and analytical (qualitative) study. The article is also a voice in the debate on tourism and urban regeneration. By displaying Persian conditions in shaping the foodscape (tourism taste-space), it contributes to the dynamically-developing research on food tourism and urban culinary space.
\end{abstract}

Keywords: Urban Revitalization (Urban Regeneration), Exhausted Neighborhood, Urban Foodscape, Tourism, Tehran.

\section{INTRODUCTION}

The regeneration of historic parts of the city with the goal of giving them new functions, particularly tourism and recreational (leisure), is a common practice all over the world (Hoffman, Fainstein, Judd, 2003). Examples of the success of many cities (especially European) based on this scheme since the second half of the $20^{\text {th }}$ century have strengthened belief in its effectiveness. It is the economic strength and benefits of developing tourism for the local economy have become most convincing, as well as the relatively easy implementation of tourism development strategies. 'Coupled system' tourismification as a tool for and aim of urban regeneration, shapes contemporary urban landscapes (often iconic cultural landscapes) from Kyoto to New Orleans, via Beijing, Mashhad, Venice and Kraków. Determined by the local context, it has different effects, although in the second decade of the $21^{\text {st }}$ century many examples show its Janus face (see the examples of Venice, New Orleans or Mashhad - see for instance Gotham, 2005; Kowalczyk-Anioł, Afshar, 2018).

The experience of western cities in the field of revitalization and the creation of (new) tourist spaces (Włodarczyk, 2011; Kazimierczak, 2012), as well as the undesirable effects of tourism development and contemporary approach to the historical urban fabric and heritage (urban cultural landscape - Taylor, 2016) suggest taking into account the interests of the local community, and in face of an awareness of the threatening consequences associated with tourismification (Jansen-Verbeke, 1998; Kowalczyk-Aniol, 2019a, 2019b), in renewing historical space.

In the current discussion on urban regeneration there is a consensus that this process should always apply to an 
area, a fragment of urban space, a district, neighborhood or at least an urban quarter (Kaczmarek, 2019). As Kaczmarek and Kazimierczak point out (2019), the purpose of such activity is to revive an area to meet the needs (current and future) of the users of this space. Despite many repetitive mechanisms, this process is contextual because the causes, course and effects of the regeneration process are topographically conditioned, i.e. dependent on the place of implementation. In this article, the context defines one of the five oldest districts of Tehran (Iran) - Oudlajan. ${ }^{1}$

The contemporary approach to urban regeneration (revitalization) exposes the comprehensive nature of this process, which includes the morphological (i.e. spatialfunctional and architectural-urban dimensions), economic, social, cultural and ecological dimensions (cf. Kaczmarek, 2019; Markowski, Stawasz, 2007; Kozłowski, Wojnarowska, 2011). The focus of the article is regeneration in the spatial, functional, architectural and urban dimensions. The area under consideration is an example of a 'problem area' whose 'malfunc-tion' is caused by social problems as well as the material and functional degradation. Therefore, the authors assume that the need for regeneration results not only from its current state of deterioration but also from its attractive location in a central space of the city. Attempts to renovate individual buildings in this district (Rezaei, Rasouli, Azhdari, 2019) have so far demonstrated the urgent need for careful planning of neighborhood change.

As Lotfi (2011) mentions, Tehran has a rich but unused historical and tourism potential (cultural and natural). Ziyaei, Abbasi, Kazemian \& Karoobi (2016) indicate that the main challenge for planning and managing tourism is that the city's attractions (disappearing in the bustle, crowds and traffic) are not noticed by tourists (coming mainly for business and medical purposes). At the same time, Tehran is one of the biggest tourist destinations in Iran (about four million tourists in 2013 - Ziyaei, Abbasi, Kazemian, Karoobi, 2016). As the capital with two international airports, is visited by the majority of foreign tourists, Tehran is at the same time a dynamic metropolis of several million whose authorities (according to the vision of the Iranian authorities - see KowalczykAnioł, Afshar, 2018) perceive tourism as a sector that can provide employment for the growing young population and improve overall living conditions.

However, as previously emphasized, despite the undeniable value of the oldest central parts of the city, their destruction continues. The accumulated neglect (of inhabitants and authorities) has resulted in the loss of urban life there and has led to their abandonment despite their worthy features (Habibi, 1999).

The research subject - the Oudlajan neighborhood - despite its potential, due to physical exhaustion is struggling with growing poverty in socio-cultural, economic and physical-spatial dimensions. The extreme exhaustion in the structure, and the lack of appropriate facil- ities and infrastructure, do not correspond with the current needs of the inhabitants. For this reason, residents living in this district are migrating to other areas of the city (more prosperous and comfortable) and other migrants, often from low-income groups, are replacing them. As a result, as indicated by Kalantari, Khalilabad \& Derakhshani (2014), the process of undermining cultural convergence, deterioration in the quality of neighborhood, loss of identity and originality, a weakening of common social memory and sense of belonging is progressing, which ultimately is leading to a deepening degradation. Therefore, the revitalization of Oudlajan seems to be necessary to increase not only its attractiveness and urban vitality, but also sustainability and resilience.

Tourism is one of the ways to revive valuable historic urban fabric which has been considered in the master plan for Tehran as the future prospect of the neighborhood (Kordovani, Ghaffari, 2011). The transformation of historic city centers in the world based on the intensification of activities focused on consumer lifestyle, entertainment and culture (cf. Clark 2011), and recently increasingly strongly on gastronomy (Mand, Cilliers, 2013; Parham, 2013), is an attractive model for city authorities. This is also favored by the locally growing demand for this type of space among the very large and young population of Tehran (one quarter of residents are in their twenties - Nawracka, 2011). At the same time, the specificity of both the socio-cultural dimension (including how space is used) and the architecture of Iran (including a clear division into private, semi-private and public spaces) determines planning options, while reflection on urban regeneration processes confirms the importance of the local context.

The project proposed in this article is intended to help bring urban life and vitality back to this historic neighborhood. It refers to the shift in the position of gastronomy in the context of the emerging experience economy (Pine \& Gilmore 1999) and culinary tourism (Kowalczyk, 2016; Stasiak, 2016) as well as dissemination of so-called urban food quarters (Parham, 2013), food districts (Kowalczyk 2014), culinaryscapes (Heryanto, Sastrawati, Patandianan, 2013; Kowalczyk, 2016), and creating a competitive destination foodscape (Richards, 2015; Björk, Kauppinen-Räisänen, 2019). Its core is 'Mazeh-Sara' - a new urban food (culinary) space - combining the features of classic tourist attractions and facilities with recreational (leisure) amenities. Those addressed by the proposed Oudlajan foodscape are both tourists increasingly coming to Tehran (including foreign and domestic tourists) as well as the inhabitants of the agglomeration itself (numbering over 16 million).

In terms of purpose, the project is applied-developmental, and in terms of the methods used, it is descriptiveanalytical (qualitative).

In view of this, the purpose of the article is to present the idea behind the regeneration of the core of historical 
Tehran focusing on creating a foodscape as a recreational and tourist cultural space rooted in Persian culinary tradition. Therefore, the main research question is how can defining a 'Mazeh-Sara' in the Oudlajan neighborhood to be effective in the regeneration of urban life in the historical core of Tehran?

Secondary questions are:

- What are the characteristics of a 'Mazeh-Sara' in Oudlajan neighborhood?

- What features should be provided in a 'Mazeh-Sara' to help to restore the historical core of Tehran to urban life?

The following methods will be used to answer the above questions:

- theoretical studies (documentary): analysis of academic literature and desk research analysis

- field studies (practical): observation and photography.

\section{CHARACTERISTICS OF THE OUDLAJAN NEIGHBORHOOD}

Oudlajan is the name of a neighborhood located in the central part of Tehran and is one of the five old neighborhoods of the city (Fig. 1). It has existed since the Safavi era (1501-1736) and in the reign of Nasir al-din-Shah (1848-1896), the number of its inhabitants were increased by often rich families (Habibi, Hourcade, 2005). It has become a wealthy district, with many new large houses. Around 1785, the first embassies were founded in the area and the nearby Tehran Old Bazaar - British, Ottoman, French, Russian and later also German and Austrian. They were later moved to the north of the city (Nawracka, 2011). As Rezaei, Rasouli \& Azhdari (2019) stress 'until the early Pahlavi era of the 1930s, the Oudlajan neighborhood, located adjacent to the bazaar and the government center, was a very important residential area, and home to various social classes, especially the ruling class and nobility'. According to statistical surveys in 1905, the Oudlajan was one of the most populous (36,495 people) among the five neighborhoods of Tehran. As shown (Fig. 2) during the Qajar period (1794-1925), the area of the Oudla-jan neighborhood increased compared to the Safavi period (Abrishami, 2010).

As the city grew, many of the wealthy residents, migrated to the northern areas of Tehran. The area was abandoned and its residents were mostly replaced by incoming migrant groups, usually on low-incomes (Abrishami, 2010). After such changes, the Great Bazaar of Tehran, as a strong economic and political urban player, dominated the neighborhood. Many residential buildings were transformed into places for Bazaar-related activities, such as workshops, business units and warehouses (Bavand Consulting Engineers, 2011; Rezaei, Rasouli, Azhdari, 2019).

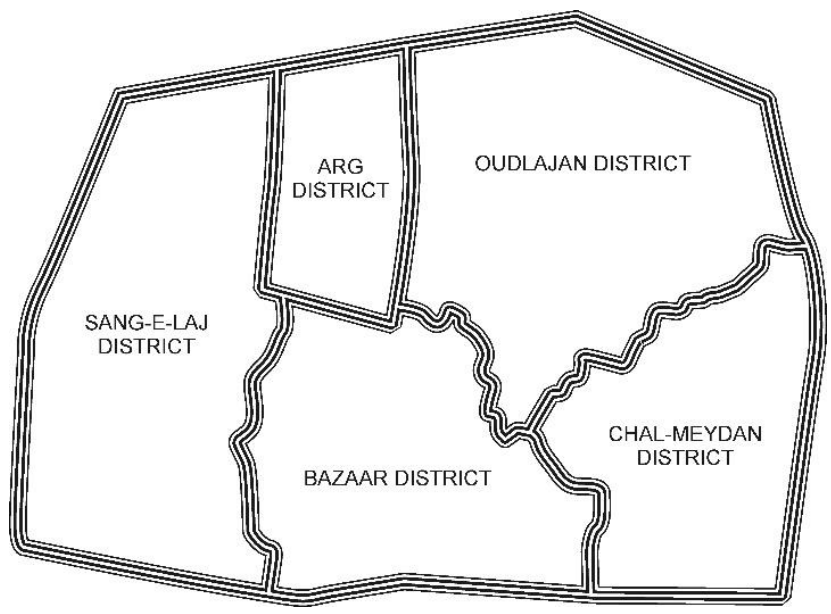

Figure 1. Old Tehran neighborhoods Source: Abrishami (2010)

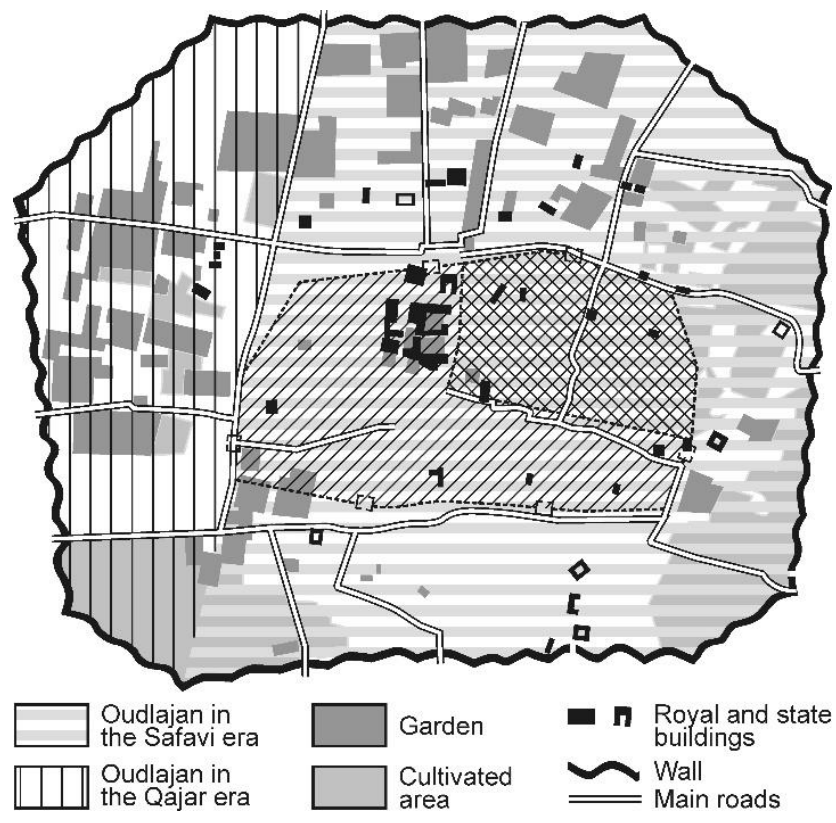

Figure 2. Oudlajan (dark) in the Safavi era; Oudlajan (light) in the Qajar era Source: Abrishami (2010)

As a result, social and cultural instability prevails in the neighborhood. This undermines cultural convergence, loss of identity and originality, diminution of common social memories and the sense of attachment and ultimately damages the neighborhood in a variety of ways.

Based on field work (observation and photography - Photos 1 and 2) carried out by the authors on April 2018, it can be concluded that the most important threats which Oudlajan is confronting nowadays are (Hakimian, 2018):

- decrease in social and personal security

- lack of appropriate local infrastructure

- lack of appropriate recreational facilities

- unstable residential buildings

- loss of historical and cultural value 
Regarding these, rehabilitation and regeneration of the neighborhood (for participation in current urban life), is essential to increase its sustainability.

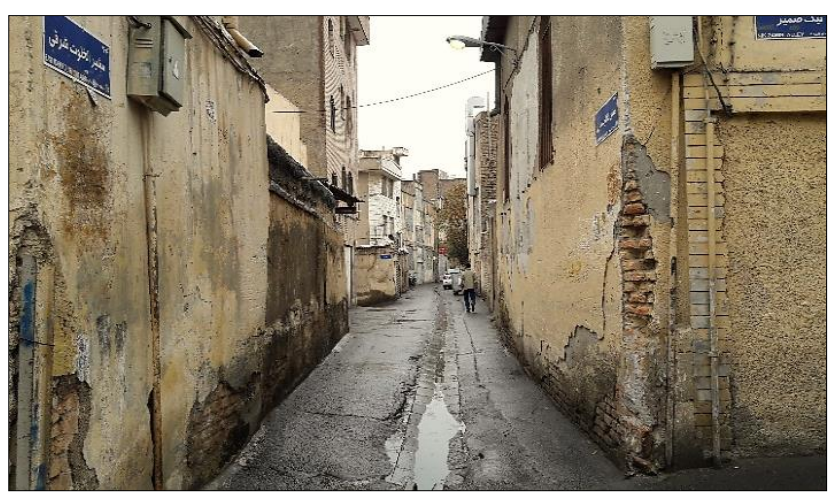

Photo 1. Weakened urban areas and lack of appropriate local infrastructure such as water, electricity, sewage etc.

Source: authors

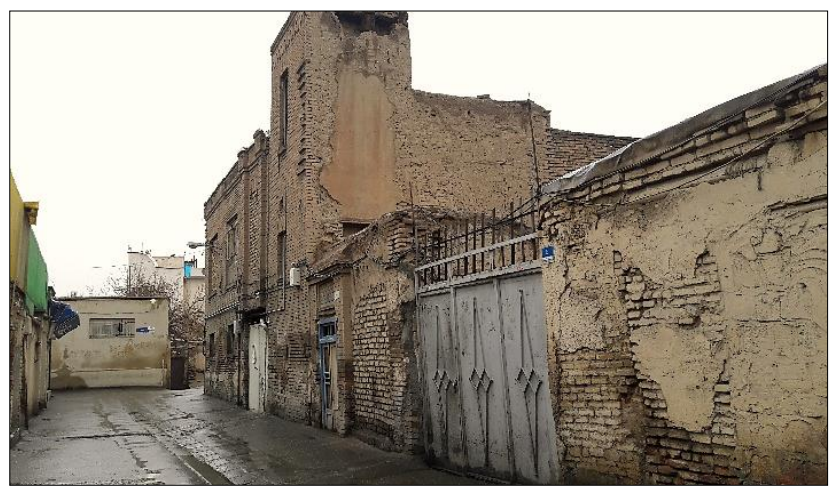

Photo 2. Low quality and poor resistance of residential buildings to natural disasters Source: authors

\section{TOURISM AND THE EXHAUSTED HISTORICAL URBAN FABRIC}

Historical urban spaces (valuable urban fabric), due to the presence of nostalgic attractions, architectural, cultural and valuable buildings and religious conditions of the period which they belong to, have the ability to increase the importance and attractiveness of the city (Dinari, 2005). They can also help the city to be considered as a tourist destination. The European model of using historical urban spaces by tourism has been discussed, for instance, by Jansen-Verbeke (1998), Ashworth \& Tunbridge (1990), Orbasli (2002), Russo (2002), Faracik (2017), García-Hernández, de la Calle-Vaquero \& Yubero (2017), KowalczykAnioł (2017). Asian examples (except Iranian, referred to in the text) were analyzed, among others by Timothy \& Wall (1995), Teo \& Huang (1995) as well as Wang \& Lee (2008).
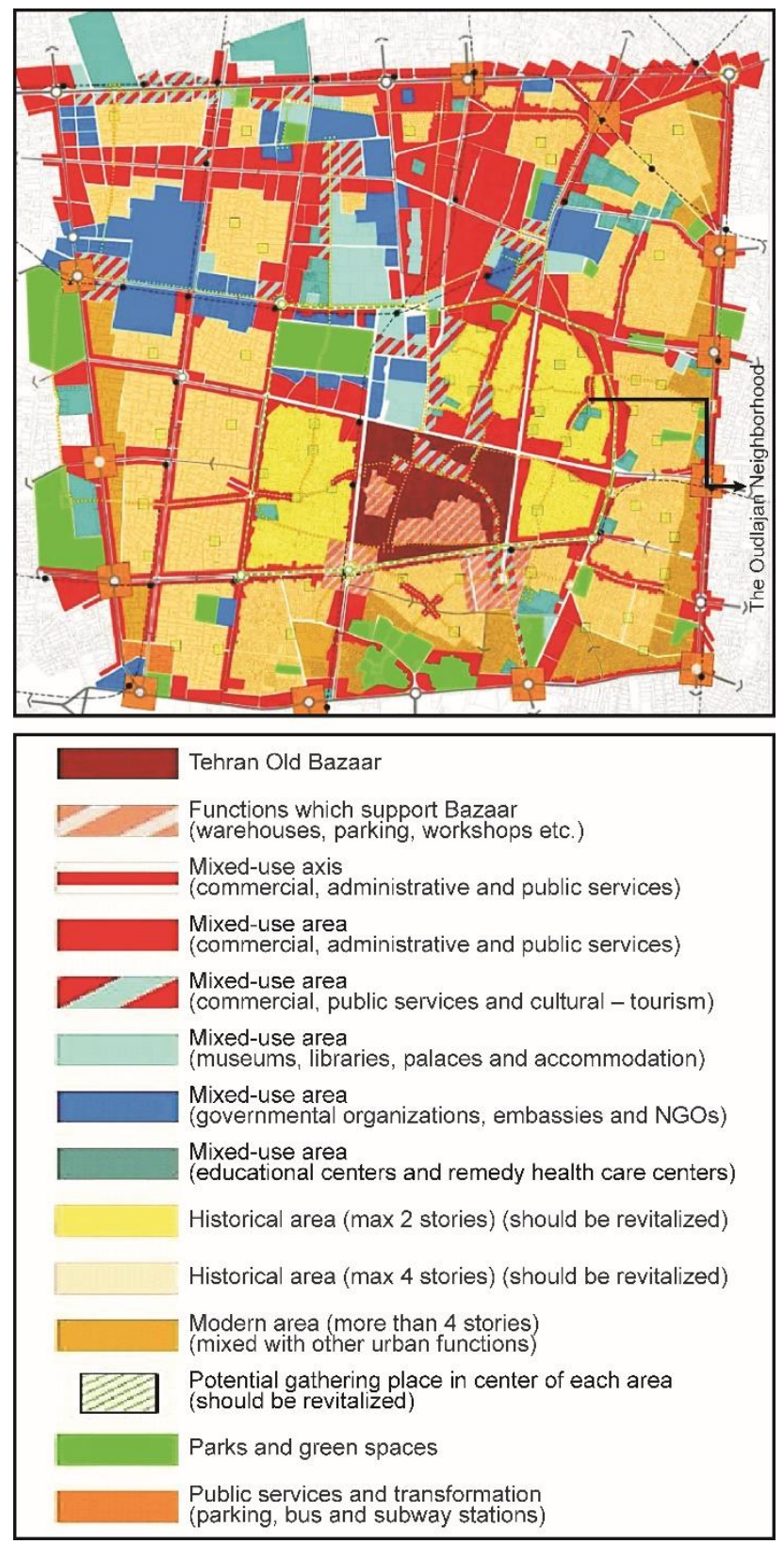

Figure 3. Investigating the district's functions Source: authors

According to Dinari (2005) historic monuments represent a significant contribution and can be reused as a space suitable for new functions or for residential, commercial, retail, entertainment and cultural purposes. Tourism can especially be used to find new functions in abandoned monuments and improve the city's physical-spatial dimension (see also Lak, Gheitasi, Timothy, 2019).

Urban tourism, due to the opportunity to create spaces and opportunities for urban historic buildings, attractions and areas of cultural heritage, makes it possible for the neighborhood to get the benefit from the positive socio-cultural and economic impacts of tourism, bring vivacity to the half dead body of the neighborhood and help tom restore these valuable, exhausted areas to life. Therefore, the representation of attractions and tourism 
facilities can be seen as a potential for urban regeneration of historical and exhausted urban spaces and to use tourism as a regeneration tool in the modern age (Movahed, Mohammadi, 2002; see also Wise, 2016).

As a result, one of the strategies recently considered as an option for the regeneration of the old core of Tehran is the expansion of tourism in historical neighborhoods (Dinari, 2005). Although Oudlajan has the potential to become an attractive tourist area, so far the opportunities for the regeneration of its historical urban fabric have not been used (Kalantari, Khalilabad, Derakhshani, 2014). Adverse changes taking place in Oudlajan, require appropriate activity to restore life to this part of the city (Habibi, 1999), and at the same time supply the constantly growing demand in Tehran for attractive public spaces and meeting places corresponding to changing social needs (Sharepour, 2019; Nawracka, 2011). This constitutes an important context for the project proposed later in the article fitting into the framework considered in the master plan of the city in which tourism (tourism development and amenities) is the future prospect of the neighborhood (Kordovani, Ghaffari, 2011) - Fig. 3.

\section{4. 'MAZEH-SARA' - THE REVIVAL OF A KIND OF 'HANGOUT' IN OLD TEHRAN}

As previously mentioned, old Tehran has five neighborhoods which each contained the 'hangout' ${ }^{2}$ (paatogh - a gathering place for the local residents) - Torkaman, Ghaed, Shemtoub (2018). Oudlajan has four 'hangouts', including Nayeb Sayyed Hassan, Nayeb Muhammad Sadiq, Nayeb Ismail and Nayeb Heydar. Each was divided into several passes and alleys. In the past, these 'meeting places' included coffeehouses (ghahwe-khane), restaurants, baths (hammam), zurkhaneh, ${ }^{3}$ mosques and tekyeh $^{4}$ (Photos 3 and 4) etc. Taqi Azadarmaki, a sociologist and professor at the University of Social Sciences at the University of Tehran, said (on Jan 2015): 'We have a lot of 'hangouts' in old and new Iran, which the most important and lasting of them are the coffeehouses that with their architectural, social and political environment, have been effective in shaping major events. Alongside eating, cultural interactions including painting and storytelling, social communications, exchanging political news, business deals, dispute resolution etc., have also taken place in coffeehouses. In addition to the presence of the lower classes of society, higher level individuals and social groups were also found, and each social group was a source of activity based on their taste and interest. One group listened to the Shahnameh ${ }^{5}$ story teller, another came to exchange news and a third for commercial and economic dealings. But today, with the advent of modernism, its role has been gradually diminished in the lives of the people' (Hosseini, 2015) - Fig. 4 and Photos 3-7.
In Tehran nowadays the 'hangout' has lost its original function and it has faded especially in the historical core of the old parts of the city. They still contain the most original and oldest coffeehouses and restaurants which are very famous in terms of quality. The high quality of food, the traditional taste and antiquity of these restaurants attract many people from all corners of the city, so it can be a tourism attraction (Hosseini, 2015) - Photos 6 and 7.

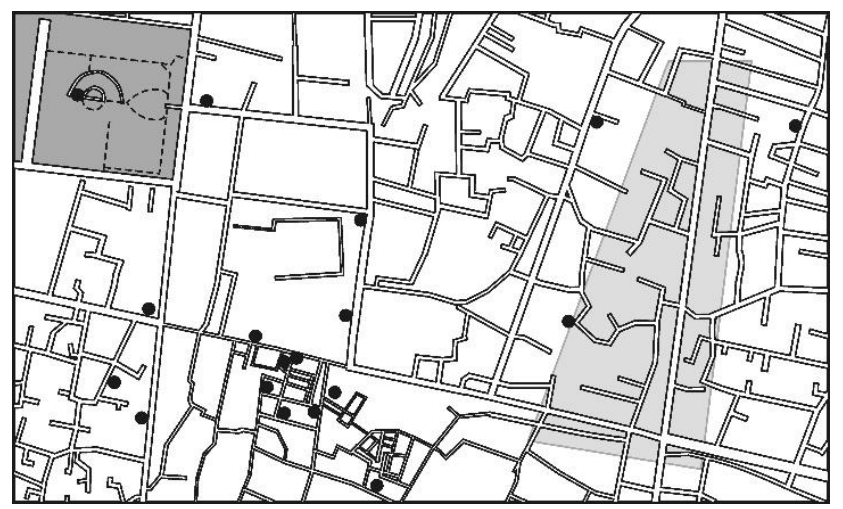

Figure 4. Original restaurants concentrated around the bazaar and Oudlajan in old Tehran Source: Maps Google (2018)

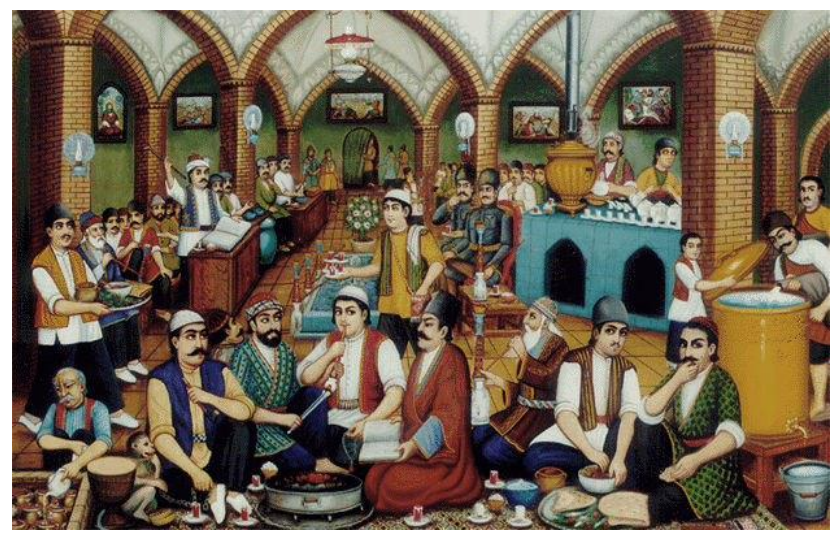

Photo 3. An old painting which shows a coffeehouse Source: Aks.ir (2019)

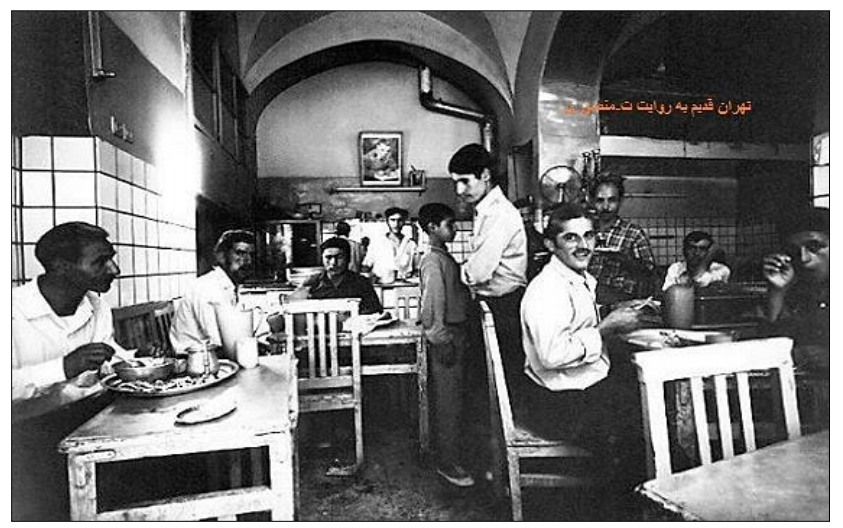

Photo 4. One of the old Tehran coffeehouses Source: Hosseini (2015) 


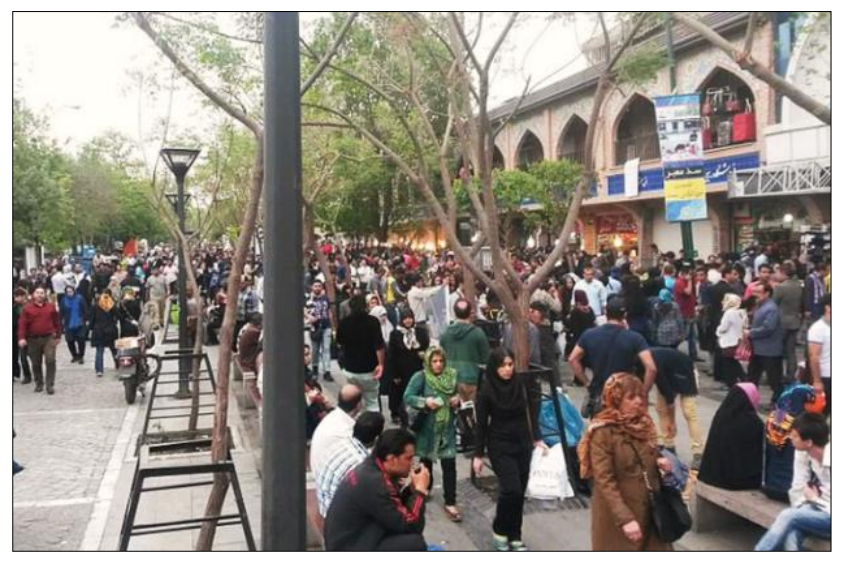

Photo 5. Everyday crowds in the Tehran bazaar Source: Kajaro.com (2018)

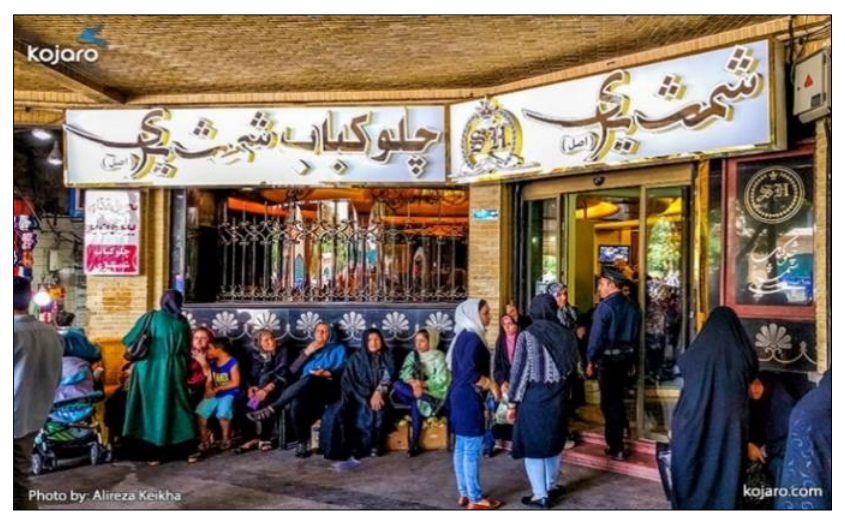

Phto 6. Crowds in front of the Shamshiri restaurant Source: Irantoorism.akaup.com (2018)

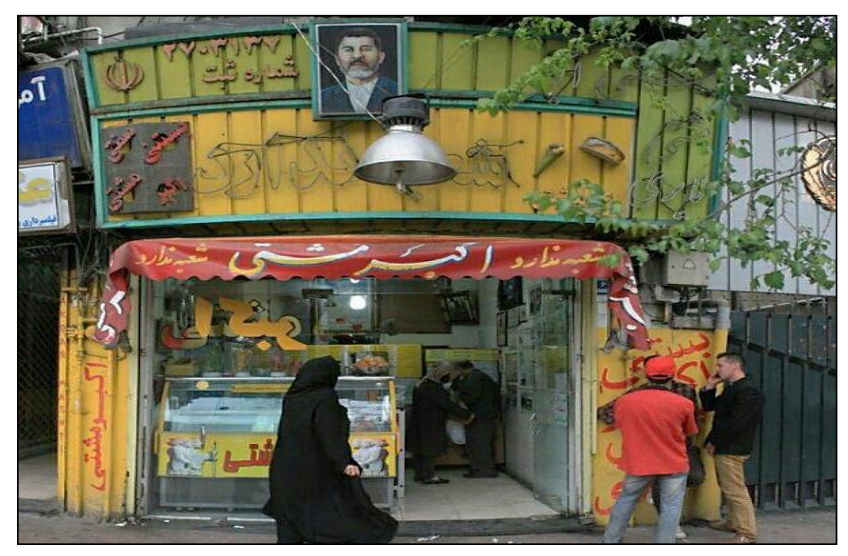

Photo 7. Akbar-mashti ice cream (an original ice cream parlor in Tehran acts as an attraction) Source: Qudsonline.ir (2019)

In Tehran nowadays the 'hangout' has lost its original function and it has faded especially in the historical core of the old parts of the city. They still contain the most original and oldest coffeehouses and restaurants which are very famous in terms of quality. The high quality of food, the traditional taste and antiquity of these restaurants attract many people from all corners of the city, so it can be a tourism attraction (Hosseini, 2015) - Photos 6 and 7.

Bearing in mind the above, 'hangouts' as effective elements in this neighborhood can be considered as a useful tool for the regeneration of Oudlajan. Based on this, a regenerated inclusive urban space called 'Mazeh-Sara' was designed in Oudlajan, which should be defined as a foodscape. A crucial aspect of the foodscape idea is that "it highlights the interaction among people, place, and food, weaving the individual into the surrounding environment, culture, and society" (Björk, Kauppinen-Räisänen, 2019, p. 468, after: Sage, 2010). Within tourism, as Björk \& Kauppinen-Räisänen (2019, p. 468) claim, "a destination foodscape denotes the places that facilitate a wide range of food experiences, beyond just restaurants and bars". With regard to foodscape management and planning, these authors recommend, among others "focus not only on environments, which are staged for tourists, but also on the everyday lives of the locals as strong experience-enhancing actors"; and "create places where tourists can have more private food experiences" (Björk, Kauppinen-Räisänen, 2019, p. 473). The 'Mazeh-Sara' concept is a foodscape that meets these expectations. It is a contemporary sustainable attractive leisure and tourist space which is rooted in Iranian sentiment for 'hangouts', thus it is possible to revive this neighborhood and bring it back into the life of the city. The immediate vicinity of the Bazaar (as the commercial hub of Tehran) should also be considered as a locational advantage of 'MazehSara'.

As a summary, it should be clarified that 'MazehSara' is a proposed name for the Oudlajan foodscape. It is derived from 'Mazeh' which means taste and 'Sara' which means a very large house in Persian. Therefore, 'Mazeh-Sara' means an extensive building for different tastes.

\subsection{THE FEATURES OF MAZEH-SARA}

The necessary features of a successful 'Mazeh-Sara' which this paper proposes include location, architectural elements, spatial organization, and interior design:

Location:

- within the proposed land use (commercial-cultural and tourism) in the master plan of Tehran.

- based on the identification of target customers to determine its overall model.

Architectural elements:

- Distinct entrance: in crowded or overcrowded environments, the facade of the restaurant should be such that it looks distinct and appealing. The restaurant's signboard is one of the most important components in the restaurants exterior design and a distinguishing feature, as it attracts the attention of the customer 
and remains in their minds. Those signboards which have a clear and at the same time very attractive message, are very influential. Old buildings in Oudlajan usually have remarkable main entrances.

- Using natural and architectural elements (derived from the architectural identity of the neighborhood), they make the space more enjoyable although the customer may not see these signs or ignore them (Mostaeddi, 2011).

Spatial organization:

- The environment of a restaurant should not be so small that the tables are too close to each other because customers feel insecure and cannot calmly eat their food.

- Viewable kitchen: the restaurants where the kitchen and its serving section are visible, and the customer can see all the work that is done for meals, are more appropriate, as restaurant staff should pay more attention to health and professional cookery (Mostaeddi, 2011).

Interior design:

- Identify target customers and define a concept, style and general theme: after identifying a general pattern, a concept and style must be identified as well as the decorative elements chosen to help bring the space closer to the desired theme.

- The foodscape should be well aware of its audience and consider factors such as age, income level, gender, marital status, and religion.

- Natural light: this element has great potential in attracting passers-by who at first do not decide to come in. In fact, it can spark the curiosity of pedestrians and encourage them to decide to come in

- Colors: colors are factors that have a very high mental impact and can create a good feeling for the customer

- Enough space for seats in busy times

- Environment and sanitation

- Comfortable furniture in an attractive and innovative design

\subsection{PLAN FOR 'OUDLAJAN MAZEH-SARA'}

According to this categorization the proposed plan for 'Oudlajan Mazeh-Sara' is as follows:

- the proposed tourism district is in the southwest of the neighborhood as a future vision in the master plan of Tehran - see Fig. 3.

- the target customers comprise tourists (international or even Iranian tourists) and residents of Oudlajan and surrounding areas.

These two groups show a different pattern of behavior in the context of the neghborhood.

Tourists spend most of their time in a range of protected historical buildings which are valuable (deter- mined on the basis of the value of a building as a historical monument, its symbolic value and its location on attractive urban places), as well as buildings without any historical value (rows of shops). Local residents spend most of their time in those (residential, commercial, administrative, cultural and etc.). Therefore, in order to locate the complex in such a way that it is easily accessible for each of these groups, we chose a place which the majority of attractions are found near residential units, which in fact is almost at the center of the neighborhood (Fig. 5).

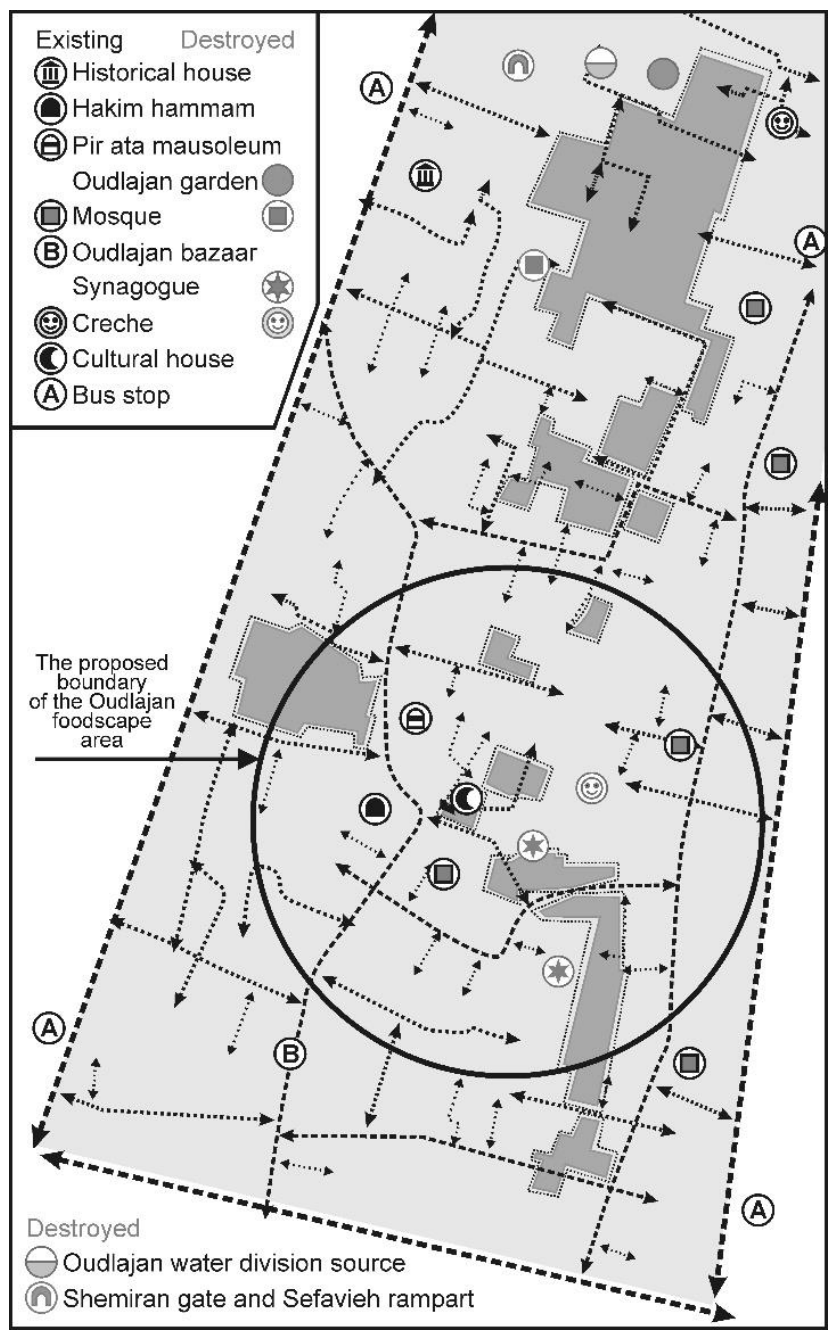

Figure 5. Buildings in the Oudlajan neighborhood Source: authors

As a result, we have the two following models:

- inside a valuable historical building (paradigm 1) - Fig. 6

- inside a building without historical value (paradigm 2) - Fig. 7

The final boundary and plan for Oudlajan 'MazehSara' would be as shown in Fig. 8. 

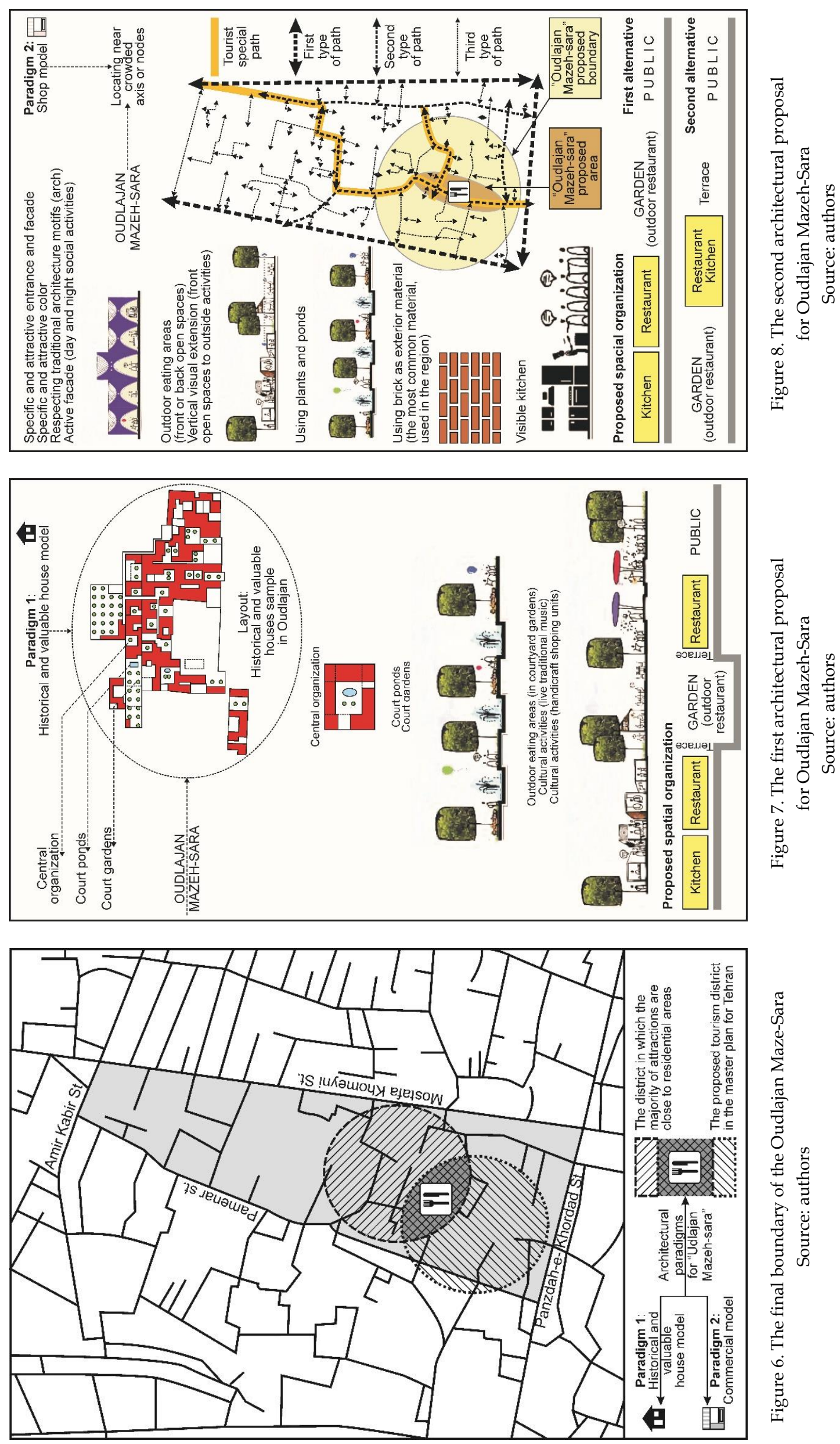


\subsection{ARCHITECTURAL PROPOSALS (BASED ON LOCATION)}

The architectural proposals for each model:

1. Paradigm 1 (historical and valuable house) - if the complex is placed inside a valuable historical protected building:

- use natural and architectural elements (derived from the architectural identity of the neighborhood), a kind of rehabilitation of abandoned potential in the heart of these houses, such as:

- a - central organization, b - courtyard, c - existence of water and plants in the courtyard

- mix the 'Mazeh-Sara' with cultural and artistic activities, in order to increase its spatial attractiveness and attract more people

- create an opportunity for outdoor service in order to create spatial diversity responses to different tastes and the usability of the space throughout the year

2. Paradigm 2 (commercial) - if placed in a range of buildings without historical value:

- distinct entrance

- use natural and architectural elements (derived from the architectural identity of the neighborhood), such as Iranian special tiling, brickwork, arched architectural motifs and the existence of water and plant elements in the courtyard

- mix functions, as explained before

- create an opportunity for outdoor service, as explained before

- the kitchen is visible

- use attractive and inviting colors (on the facade and in the interior design)

- use window (natural light) in order to create a visual extension between inside and outside using interior decorations (derived from the architectural identity of the neighborhood), as explained before.

\section{CONCLUSIONS}

Despite many restrictions, including international sanctions, tourism (and the tourism industry) has grown rapidly in Iran (Seyfi, Hall, Kuhzady, 2019). However, its development is still a new phenomenon, and as Alipour \& Heydari claim (2005, p. 39) 'encouraging 'tourism' in Iran has become a hotly debated issue (see Seyfi, Hall, 2018).

The proposal presented in the article is a project to revive city life in one of the five historic districts of Tehran and relates to both the contemporary needs of this place and its potential. In the fundamental idea, the project uses the Iranian tradition of 'hangouts' and refers to current trends in spending free time in a city as well as shaping (designing) urban space. Contemporary urban tourism spaces are evolving into urban leisure spaces that are attractive to both tourists and residents (including residents of other city districts). Their inseparable component, closely related to growing consumerism and experience economy, is a proliferation of eating places (Parham, 2013; Heryanto, Sastrawati, Patandianan, 2013; Kowalczyk, 2014; Richards, 2015; Björk, Kauppinen-Räisänen, 2019). As in western cities, in urban space they are materialized in the form of food courts located in historical or post-industrial (which is typical in Western cities) revitalized urban fabric. The presented project is to help introduce the tourist function (based on culinary traditions and search for gastronomic experiences) in the non-tourist space of the city. Bearing in mind the experiences of many cities, the authors are aware of the opportunities and threats that such activity brings (see other Iranian cases - Yazd (Rezaei, 2017) and Masshad (Kowalczyk-Anioł, Afshar, 2018). At the initial stage of creating the idea, we assume a meeting space, inclusive for both Tehran residents and tourists, but also a culturally themed culinary space (Chaudhuri, Fowler, Sinha, 2018). This project is an attempt to halt the progressive degradation of the historical fabric of the district, to restore Oudlajan's life and also to restore its identity.

The article is a voice in the wide debate on tourism and regeneration aimed at creating an urban tourism tastespace (Everett, 2019). By displaying Persian conditions in shaping a foodscape, it contributes to food tourism research which itself is dynamically developing (Ellis, Park, Kim, Yeoman, 2018). At the same time, it indicates possibilities for further research, of which the functioning of a foodscape as a travelling concept $(\mathrm{Bal}, 2002)$ seems particularly attractive both to various academic disciplines as well as the cultural and political contexts of urban space.

\section{ENDNOTES}

${ }^{1}$ Tehran, although it has a long and complicated history (associated with the nearby ancient city of Rey located on the Silk Road) has gained its current form over the past three centuries. With the acquisition of capital city functions, from a small town of 15,000 residents it has developed into a large metropolis of several million - see more Nawracka (2011).

2 'Hangout' is also associated with the roots of Oldenburg's 'third place' concept (1989).

${ }^{3}$ A traditional system of athletics originally used to train warriors (Pahlevani and zoorkhaneh rituals, 2019).

4 A place where Shiite Muslims gather to mourn Muharram, such places are in particular found in Iran. They are usually designed with elements of Persian architecture (Tekyeh, 2019).

${ }^{5}$ Is a long epic poem written by the Persian poet Ferdowsi between c. 977 and 1010 CE (Shahnameh, 2019). 


\section{REFERENCES}

Abrishami, F. (2010). Tehran of ancient times. Tehran: Khaneye Tarikh va Tasvire Abrishami (in Persian).

Aks.ir (2019). Retrieved from: http://aks1.ir/index.php/123456789/IRAN-101 (9.10.2019).

Alipour, H., Heydari, R. (2005). Tourism revival and planning in Islamic Republic of Iran: Challenges and prospects. Anatolia $16(1), 39-61$.

Ashworth, G.J., Tunbridge, J.E. (1990). The tourist-historic city. London: Belhaven.

Bal, M. (2002). Travelling concepts in the humanities: A rough guide. Toronto: University of Toronto Press.

Bavand Consulting Engineers. (2011). Urban renewal plan of Oudlajan neighborhood. Tehran: Urban Renewal Organization of Tehran.

Björk, P., Kauppinen-Räisänen, H. (2019). Destination foodscape: A stage for travelers' food experience. Tourism Management, $71,466-475$.

Chaudhuri, H.R., Fowler, J.G., Sinha S.M. (2018). Market-mediated authenticity in culturally themed culinary space. Qualitative Market Research: An International Journal, 21 (3), 353-374. DOI: https://doi.org/10.1108/QMR-07-2016-0059

Dinari, A. (2005). Urban tourism in Iran and the world. Tehran: Vajegane kherad (in Persian).

Dining court, design criteria (Westland Mall). (2014, Jun). Chicago: Star Wood Retail Patern. https:/ / starwoodretail.com/files/WST_Tenant\%20Design\%20Crigeria\%20-\%20Food\%20Court_060114.pdf.

Ellis, A., Park, E., Kim, S., Yeoman, I. (2018). What is food tourism? Tourism Management, 68, 250-263. DOI: https://doi.org/10.1016/j.tourman.2018.03.025

Everett, S. (2019). Theoretical turns through tourism taste-scapes: the evolution of food tourism research. Research in Hospitality Management, 9 (1), 3-12.

Faracik, R. (2017). The historic town of Sandomierz as a tourist destination. Turyzm/ Tourism, 27 (2), 35-43.

García-Hernández, M., de la Calle-Vaquero, M., Yubero, C. (2017). Cultural heritage and urban tourism: Historic city centres under pressure. Sustainability, 9 (8), 1346.

Habibi, M. (1999). Tourism walking route. Journal of Tehran Fine Arts University: Architecture and Urban Design, 9, 43 (in Persian).

Habibi M., Hourcade B., (2005). Atlas of Tehran Metropolis. Tehran: Tehran Geographic Information Center (TGIC).

Hakimian, S. (2018). Tourism, residential, cultural complexes designing in the Fabric of Oudlajan neighborhood with emphasis on the revival of Persian architecture lost heritage. Master thesis. Department of Art and Architecture, Islamic Azad University: South Tehran Branch.

Heryanto B., Sastrawati I., Patandianan M.V., 2013, Culinaryscape: typomorphological changes in old district urban landscape. Revista Lusófona de Arquitectura e Educação, 8-9, 205-222.

Hoffman L., Fainstein S., Judd D. (eds.), 2003, Cities and visitors Regulating people, markets and city space. Oxford, UK: Blackwell.

Hosseini, M. (2015). Hanging out in Tehran from the past to the present. Rahe Mardom Newspaper, 2475, 31. Jan. https://www.irna.ir/news/ 81485765 (in Persian).

Irantoorism.akaup.com (2018). Retrieved from: http://irantoorism. akaup.com/iranshenasi-irangardi/safar1/news2016981935784636. html (28.03.2019).

Jansen-Verbeke, M. (1998). Tourismification of historical cities. Annals of Tourism Research, 25, 3, 739-742.

Kaczmarek, S. (2019). Ruining, demolition and regeneration in urban space: sketching the research problem. Geographia Polonica, 92, 1, 5-16.
Kaczmarek, S. (ed.) (2019). Demolowanie w kontkście teorii rewitalizacji miast. Łódź: Wydawnictwo Uniwersytetu Łódzkiego.

Kaczmarek, S., Kazimierczak, J. (2019), Rewitalizacja i jej cechy, In: S. Kaczmarek (ed.), Demolowanie w kontkście teorii rewitalizacji miast (pp. 55-78). Łódź: Wydawnictwo Uniwersytetu Łódzkiego.

Kajaro.com (2018). Retrieved from: www.kojaro.com (25.03.2018).

Kalantari Khalilabad, H., Derakhshani, N. (2014). Corporal-social sustainability guidelines in historic sites, case study: Oudlajan parish (Tehran). Journal of Urban Studies, 3, 10, 3-14 (in Persian).

Kardovani, P., Ghffari V. (2011). Tourism and regeneration approach in the design of urban historical fabrics. Journal of The Geography of the Land, 30 (in Persian).

Kazimierczak, J. (2012). The influence of the revitalization of former industrial urban areas on new urban and tourism spaces: Case studies of Manchester and Lyon. Turyzm/Tourism, 22 (1), 11-20.

Kowalczyk, A. (2014). Od street food do food districts - usługi gastronomiczne i turystyka kulinarna w przestrzeni miasta. Turystyka Kulturowa, 9, 6-31.

Kowalczyk, A. (2016). Turystyka kulinarna - podejścia 'geograficzne' i 'niegeograficzne'. Turystyka Kulturowa, 5, $29-59$.

Kowalczyk-Anioł, J. (2017). The Venice syndrome of heritage cities. Evidences of tourism development dysfunctions in Poland. Designing for co-creation in Euro-Asian tourism 2017 (pp. 2839). Nara and Shirahama: Proceedings of the EATSA Conference.

Kowalczyk-Aniol, J. (2019a). Tourismification of the housing resources of historical inner cities. The case of Kraków, Studia Miejskie (in print).

Kowalczyk-Anioł, J. (2019b). Urban tourism hypertrophy as a challenge for urban resilience. Paper presented during IGU Urban Commission Meeting Luxembourg: Urban Challenges in a complex World, 4th-9th August 2019. https://www.unil.ch/igu-urban/home/menuinst/meetings/2019-luxembourg.html.

Kowalczyk-Anioł, J., Afshar, A. (2018). Gentryfikacja turystyczna jako narzędzie rozwoju miasta. Przykład Meszhed w Iranie. Turystyka Kulturowa, 2, 7-25.

Kozłowski, S., Wojnarowska, A. (2011). Rewitalizacja zdegradowanych obszarów miejskich. Zagadnienia teoretyczne. Łódź: Wydawnictwo Uniwersytetu Łódzkiego.

Lak, A., Gheitasi, M., Timothy, D.J. (2019). Urban regeneration through heritage tourism: cultural policies and strategic management. Journal of Tourism and Cultural Change, 1-18. DOI: https://doi.org/10.1080/14766825.2019.1668002

Lotfi, S. (2011). The genealogy of urban regeneration: From reconstruction to Renaissance. Tehran: Azarakhsh (in Persian).

Mand, H. N., Cilliers, S. (2013). Hospitable urban spaces and diversity. Hospitality $\mathcal{E}$ Society, 3 (3), 211-228. DOI: https://doi.org/10.1386/hosp.3.3.211_1

Maps Google (2019). Retrieved from: https://www.google.com/maps. (25.03.2018).

The master plan of district 12 of Tehran. (2006). Teheren: Ministry of Housing and Urban Development - Tehran Municipality, Center of Study and Planning of Tehran City.

Mostaeddi, A. (2011). Café and Restaurant Design. Tehran: Fakhrakia (in Persian).

Movahed, A., Mohammadi, M. (2002). Investigation and analysis of spatial pattern of urban tourism. Case study: Isfahan City. Ph.D. dissertation. Department of Tourism Management, Tarbiat Modarres University, Teheran (in Persian).

Nawracka, M. J. (2011). Przestrzenie Teheranu - miasta kontrastów. Etnografia Polska, 55 (1-2), 199-226.

Oldenburg, R. (1989). The great good place: Café, coffee shops, community centers, beauty parlors, general stores, bars, hangouts, and how they get you through the day. New York: Paragon House. 
Orbasli, A. (2002). Tourists in historic towns: Urban conservation and heritage management. London: Taylor \& Francis. DOI: https://doi.org/10.4324/9780203479001

Pahlevani and zoorkhaneh rituals (2019). Retrived from: https://en.wikipedia.org/wiki/Pahlevani_and_zoorkhaneh_rituals (9.10.2019).

Parham, S. (2013). Market place: Food quarters, design and urban renewal in London. Newcastle upon Tyne: Cambridge Scholars Publishing.

Pine, B.J., Gilmore, J.H. (1999). The experience economy. Harvard: Harvard University Press.

Qudsonline.ir (2018). Retrieved from: http://www.qudsonline.ir/news/114393 (25.03.2018).

Rezaei, N. (2017). Resident perceptions toward tourism impacts in historic center of Yazd, Iran. Tourism Geographies, 19 (5), 734755. DOI: https://doi.org/10.1080/14616688.2017.1331261

Rezaei, N., Rasouli, M., Azhdari, B. (2018). The attitude of the local community to the impact of building reuse: Three cases in an Old Neighborhood of Tehran. Heritage \& Society, 11 (2), 105-125. DOI: https://doi.org/10.1080/2159032X.2019.1583805

Richards, G. (2015). Evolving gastronomic experiences: From food to foodies to foodscapes. Journal of Gastronomy and Tourism, 1 (1) 5-17. DOI: https://doi.org/10.3727/216929715X14298190828796

Russo, A.P. (2002). The "vicious circle" of tourism development in heritage cities. Annals of Tourism Research, 29 (1), 165-182. DOI: https://doi.org/10.1016/S0160-7383(01)00029-9

Seyfi, S., Hall, C.M. (eds.). (2018). Tourism in Iran: Challenges, development and issues. Abingdon: Routledge.

Seyfi, S., Hall, C.M., Kuhzady, S. (2019). Tourism and hospitality research on Iran: Current state and perspectives. Tourism Geographies, 21 (1), 143-162. DOI: https://doi.org/10.1080/14616688.2018.1454506

Shahnameh (2019). Retrieved from: https://en.wikipedia.org/wiki/Shahnameh (9.10.2019).

Sharepour M., 2019, Transformation of public space: Assessing the publicness of urban public places in the Iranian context (presentation). "Cities the $21^{\text {st }}$ century" Inspirations and effects of planning and management of the city development - 26-28 May 2019, Opole (Poland)
Stasiak, A. (2016). Turystyka kulinarna w gospodarce doświadczeń. Turystyka Kulturowa, 5, 6-28.

Statistical Center of Iran's General Survey (2011). Retrieved from: http://www.amar.org.ir/Portals/0/Files/abstract/1390/sarshomari90_nahaii.pdf (21.05.2014).

Taylor, K. (2016). The historic urban landscape paradigm and cities as cultural landscapes. Challenging orthodoxy in urban conservation. Landscape Research, 41 (4), 471-480. DOI: https:/ / doi.org/10.1080/01426397.2016.1156066

Tekyeh (2019). Retrieved from: https://en.wikipedia.org/wiki/Tekyeh (9.10.2019).

Teo, P., Huang, S. (1995). Tourism and heritage conservation in Singapore. Annals of Tourism Research, 22 (3), 589-615. DOI: https://doi.org/10.1016/0160-7383(95)00003-0

Timothy, D. J., Wall, G. (1995). Tourist accommodation in an Asian historic city. Journal of Tourism Studies, 6 (2), 63-73.

Torkaman, A., Ghaed, M., Shemtoub, S. (2018). Hangout, the urban and architectural public space for social and cultural interactions (Case study: Borazjan city). Research And Urban Planning, 8 (31), 225-248.

Travel guide to Tehran (2018). Retrieved from: https:/ /www.kojaro.com/2016/3/5/117603/travel-guide-to-tehran-p4/ (25.03.2018).

Wang, H. J., Lee, H. Y. (2008). How government-funded projects have revitalized historic streetscapes. Two cases in Taiwan. Cities, 25 (4), 197-206. DOI: https://doi.org/10.1016/j.cities.2008.04.007

Wise, N. (2016). Outlining triple bottom line contexts in urban tourism regeneration. Cities, 53, 30-34. DOI: https://doi.org/10.1016/j.cities.2016.01.003

Włodarczyk, B. (2011). Processes of tourism space formation Turyzm/Tourism, 21 (1-2), 59-65. DOI: https://doi.org/10.2478/v10106-011-0007-3

Ziyaei, M., Abbasi, K.D., Kazemian, G., Karoobi, M. (2016). Identification and determination of dimensions of tourism management model in Tehran. The Scientific-Research Quarterly. Journal of Urban Economics and Management, 4 (13), 117-137.

Article received:

20 August 2019

Accepted:

14 October 2019 
